\title{
Polyamine Oxidases Play Various Roles in Plant Development and Abiotic Stress Tolerance
}

\author{
Zhen Yu ${ }^{1}$, Dongyu Jia ${ }^{2}$ and Taibo Liu ${ }^{1, *}$ \\ 1 State Key Laboratory for Conservation and Utilization of Subtropical Agro-Bioresources, Guangdong \\ Provincial Key Laboratory of Protein Function and Regulation in Agricultural Organisms, College of Life \\ Sciences, South China Agricultural University, Guangzhou 510642, China; yuzhen5500@163.com \\ 2 Department of Biology, Georgia Southern University, Statesboro, GA 30460-8042, USA; \\ djia@georgiasouthern.edu \\ * Correspondence: tbliu@scau.edu.cn; Tel.: +86-20-3829-7785
}

Received: 29 April 2019; Accepted: 20 June 2019; Published: 21 June 2019

\begin{abstract}
Polyamines not only play roles in plant growth and development, but also adapt to environmental stresses. Polyamines can be oxidized by copper-containing diamine oxidases (CuAOs) and flavin-containing polyamine oxidases (PAOs). Two types of PAOs exist in the plant kingdom; one type catalyzes the back conversion (BC-type) pathway and the other catalyzes the terminal catabolism (TC-type) pathway. The catabolic features and biological functions of plant PAOs have been investigated in various plants in the past years. In this review, we focus on the advance of PAO studies in rice, Arabidopsis, and tomato, and other plant species.
\end{abstract}

Keywords: back conversion pathway; polyamines; polyamine oxidase; polyamine catabolism; stress response; terminal catabolism pathway

\section{Introduction}

Polyamines (PAs) are aliphatic amines of small molecular mass that are involved in various biological processes [1,2]. The putrescine (Put), cadaverine (Cad), spermidine (Spd), spermine (Spm), and thermospermine (T-Spm) are the major plant PAs [1-7]. PAs play important roles in embryogenesis, cell division, organogenesis, flowering, programmed cell death (PCD), response to abiotic and biotic stresses, and so on [4-33].

The homeostasis of cellular PA levels, being well regulated by a dynamic balance of biosynthesis and catabolism, is most important for maintaining normal growth and development in plants. The PA biosynthetic pathway has been well elucidated $[1,34,35]$, however, the PA catabolism pathway remains unclear in spite of more and more newly identified genes in this pathway in plants [4,36-56]. In this review, we summarized the advances of the polyamine oxidases' (PAOs) roles in PA catabolism, plant development, and abiotic stress tolerance from rice, Arabidopsis, tomato, and other plant species.

\section{PA Biosynthesis in Plants}

Plant PA biosynthesis is rather short, which starts mainly from arginine (Arg). The pathway is briefly shown in Figure 1 and is described as follows. Firstly, Arg is converted to Put via agmatine by three sequential reactions catalyzed by arginine decarboxylase (ADC, EC 4.1.1.19), agmatine iminohydrolase (AIH, EC 3.5.3.12), and N-carbamoylputrescine amidohydrolase (CPA, EC 3.5.1.53). Besides, some plants have the ornithine decarboxylase (ODC, EC 4.1.1.17) which catalyzes ornithine to Put directly [57], but Arabidopsis has only the ADC pathway because it lacks ODC genes. Secondly, the diamine Put is converted to triamine Spd by Spd synthase (SPDS, EC 2.5.1.16). Finally, Spd is further converted to Spm or T-Spm, two tetraamine isomers, by Spm synthase (SPMS, EC 2.5.1.22) and 
T-Spm synthase (ACAULIS5, abbreviated to ACL5), respectively $[9,19,47,58]$. An aminopropyl group is transferred from the decarboxylated S-adenosylmethionine (dcSAM) produced from methionine in two sequential reactions catalyzed by methionine adenosyltransferase and $S$-adenosylmethionine decarboxylase (SAMDC), respectively. These aminopropyl groups participate in the biochemical reaction of Spd, Spm, and T-Spm biosynthesis processes. Additionally, norspermidine (NorSpd) and norspermine (NorSpm), having been found as "uncommon PAs" due to their limited distribution in nature, are predicted to be synthesized either successively by each specific aminopropyl transferase (APT) or by a single APT with broad substrate specificity from 1,3-diaminopropane (1,3-DAP) [59].

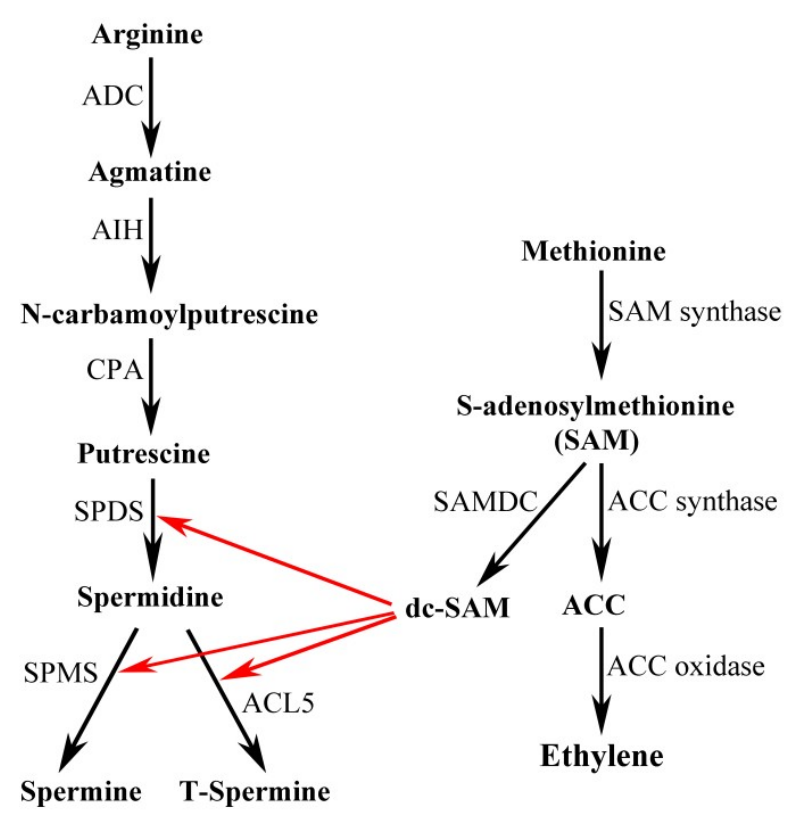

Figure 1. Polyamine biosynthesis pathway in Arabidopsis thaliana. ADC, arginine decarboxylase; $\mathrm{AIH}$, agmatine iminohydrolase; CPA, N-carbamoylputrescine amidohydrolase; SPDS, Spd synthase; SPMS, Spm synthase; ACL5, ACAULIS5, T-Spm synthase; SAM, S-adenosylmethionine; SAMDC, S-adenosylmethionine decarboxylase; dcSAM, decarboxylated S-adenosylmethionine; ACC, 1-amino-cyclopropane-1-carboxylic-acid.

\section{PA Catabolism in Plants}

PA biosynthetic pathways have been well investigated. In contrast, the knowledge on PA catabolism in plants is still fragmental though scholars reported some new findings in the past years. Two kinds of enzymes are involved in PA catabolism. Namely, one is a copper-dependent diamine oxidase (DAO, EC 1.4.3.6) and the other is a flavin adenine dinucleotide (FAD)-dependent polyamine oxidase (PAO, EC 1.5.3.11). PAOs, using FAD as cofactor, catalyze Spd and Spm to produce 4-aminobutanal and $\mathrm{N}$-(3-aminopropyl)-4-aminobutanal, respectively, as well as hydrogen peroxide $\left(\mathrm{H}_{2} \mathrm{O}_{2}\right)$ which acts as an important signaling to regulate the expression of numerous genes relative to the stress response in the back conversion (BC-type) pathway; in addition to 1,3-diaminopropane and $\mathrm{H}_{2} \mathrm{O}_{2}$ in the terminal catabolism (TC-type) pathway [46-49,51-54,60].

\section{PAOs in Plants}

Up to now, more and more plant PAOs have been cloned and functionally identified. In Figure 2, we analyzed the phylogenetic relationship among seventy-three plant PAOs from twenty-four species. The plant PAOs are grouped into five clades $I \sim V$ in the phylogenetic tree, as shown in Figure 2. Clade-I has nine members including Arabidopsis PAO (AtPAO1) and tomato PAO (SIPAO1) [48,61-63]. Clade-II contains sixteen genes including three rice PAOs (OsPAO2, OsPAO6 7) $[48,60,63]$. Based on previous studies, the clade II may present apoplastic PAOs that catalyze terminal oxidation reactions $[36,42,44-$ 
$46,49,55,60]$. Clade-III consists of nineteen members including rice PAO (OsPAO1), Arabidopsis PAO (AtPAO5), and two tomato PAOs (SIPAO6 7) [49,51,63]. Clade-IV contains twenty-eight PAOs from eight different species including three rice PAOs (OsPAO3 5), three Arabidopsis PAOs (AtPAO2 4), and four tomato PAOs (SIPAO2 5) [12,47,48,50,61,63,64]. The clade $V$ so far includes only a Vitis vinifera PAO (VvPAO6). Currently, almost all PAOs of the rice and Arabidopsis have been well determined, and we recently identified the tomato PAOs. Thus, we will review on the advance of PAOs from these three species, as well as other plant species, in this manuscript.

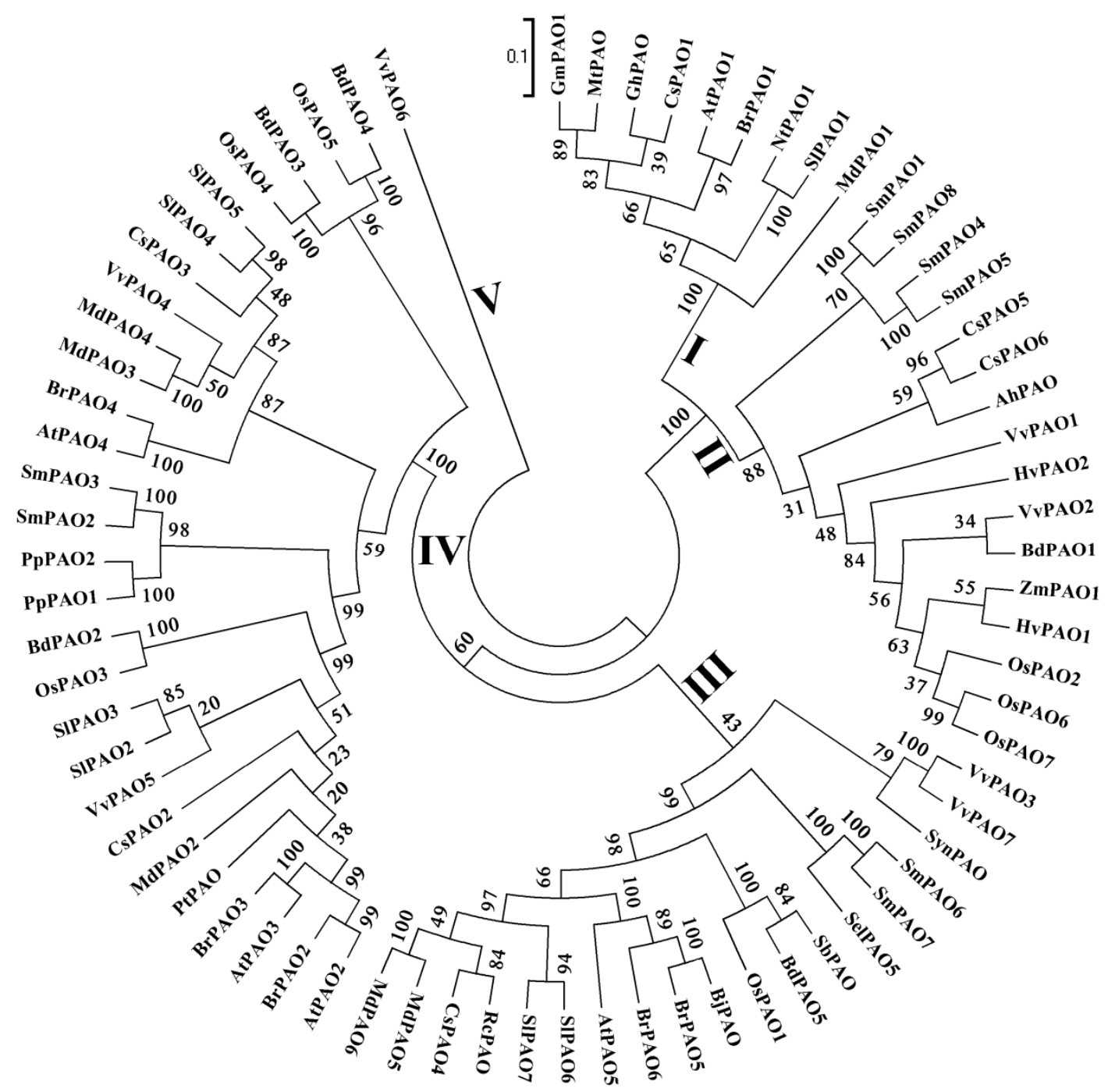

Figure 2. Phylogenetic relationship of polyamine oxidases (PAOs) among rice, Arabidopsis, tomato, and other plants. The neighbor-joining tree was constructed by amino acid sequence alignment using Clustal X 1.83 and MEGA 5.0. The bootstrap values, displayed at the branch nodes, were obtained with 1000 repetitions. Roman numerals (I V) indicate clade numbers. The analyzed genes and their accession numbers are listed in Table 1. Os, Oryza sativa; At, Arabidopsis thaliana; Sl, Solanum lycopersicum; Bd, Brachypodium distachyon; Br, Solanum lycopersicum; Cs, Citrus sinensis; Sm, Selaginella moellendorffii; Vv, Vitis vinifera; Md, Malus domestica; Sel, Selaginella lepidophylla; Zm, Zea mays; Hv, Hordeum vulgare; $\mathrm{Pp}$, Physcomitrella patens; Rc, Ricinus communis; Nt, Nicotiana tabacum; Bj, Brassica juncea; Pt, Populus trichocarpa; Sb, Sorghum bicolor; Gm, Glycine max PAO1-like; Mt, Medicago truncatula; Ah, Amaranthus hypochondriacus; Gh, Gossypium hirsutum; Syn, Synechocystis. 
Table 1. List of the accession numbers of the plant PAOs used in Figure 2.

\begin{tabular}{|c|c|c|c|c|c|c|c|}
\hline Gene Name & Accession No. & Gene Name & Accession No. & Gene Name & Accession No. & Gene Name & Accession No. \\
\hline OsPAO1 & NM_001050573 & BdPAO1 & XM_003573843 & SmPAO3 & XP_002968082.1 & PpPAO2 & XM_001776435 \\
\hline OsPAO2 & NM_001055782 & BdPAO2 & XM_010242147 & SmPAO4 & XP_002969966.1 & RcPAO & XM_002521542 \\
\hline OsPAO3 & NM_001060458 & $B d P A O 3$ & XM_003580746 & SmPAO5 & XP_002981437.1 & PtPAO & XM_002306729 \\
\hline OsPAO4 & NM_001060753 & BdPAO4 & XM_003580747 & SmPAO6 & XP_002984796.1 & SbPAO & XM_002448510 \\
\hline OsPAO5 & NM_001060754 & BdPAO5 & XM_003566997 & SmPAO7 & XP_002985859.1 & GmPAO1 & XP_003535841.1 \\
\hline OsPAO6 & XM_015755533 & BrPAO1 & Bra006210 & SmPAO8 & XP_002986593.1 & $M t P A O$ & XP_003599417.1 \\
\hline OsPAO7 & NM_001069546 & BrPAO2 & Bra037741 & VvPAO1 & VIT_01s0127g00750 & SynPAO & WP_011153630.1 \\
\hline AtPAO1 & NM_121373 & BrPAO3 & Bra003362 & $V v P A O 2$ & VIT_01s0127g00800 & PpPAO1 & XM_001756812 \\
\hline AtPAO2 & AF364952 & BrPAO4 & Bra039742 & VvPAO3 & VIT_03s0017g01000 & $\mathrm{ZmPAO1}$ & NM_001111636 \\
\hline AtPAO3 & AY143905 & BrPAO5 & Bra011132 & $V v P A O 4$ & VIT_04s0043g00220 & AhPAO & AAM43922.1 \\
\hline AtPAO4 & AF364953 & BrPAO6 & Bra024137 & VvPAO5 & VIT_12s0028g01120 & GhPAO & KC762210.1 \\
\hline AtPAO5 & AK118203 & CsPAO1 & Cs7g02060.1 & VvPAO6 & VIT_12s0055g00480 & $H v P A O 1$ & AJ298131 \\
\hline SIPAO1 & XP_004229651 & CsPAO2 & Cs7g18840.2 & VvPAO7 & VIT_13s0019g04820 & $\mathrm{HvPAO} 2$ & AJ298132 \\
\hline SIPAO2 & XP_004243630 & CsPAO3 & Cs6g15870.1 & $M d P A O 1$ & ANJ77637.1 & SelPAO5 & LC036642 \\
\hline SIPAO3 & XP_004251556 & CsPAO4 & Cs4g14150.1 & MdPAO2 & ANJ77639.1 & NtPAO & AB200262 \\
\hline SIPAO4 & XP_004232664 & CsPAO5 & Cs7g23790.1 & $M d P A O 3$ & ANJ77642.1 & BjPAO & AY188087 \\
\hline SIPAO5 & XP_004234492 & CsPAO6 & Cs7g23760.1 & MdPAO4 & ANJ77638.1 & & \\
\hline SIPAO6 & XP_004243758 & SmPAO1 & XP_002965265.1 & MdPAO5 & ANJ77640.1 & & \\
\hline SIPAO7 & XP_004239292 & SmPAO2 & XP_002965599.1 & MdPAO6 & ANJ77641.1 & & \\
\hline
\end{tabular}




\subsection{Rice PAOs}

Ono et al. reported that seven PAOs exist in rice, orderly named as OsPAO1 OsPAO7 [47]. He and his colleagues found OsPAO3 5 are similarly and highly expressed in two-week-old seedlings and mature plants, whereas the other four OsPAO members are only expressed at very low levels in all tissues. Especially, OsPAO2, OsPAO6, and OsPAO7 are expressed at almost negligible levels, as shown in Table $2[47,49]$. They also found the purified recombinant OsPAO3 strongly catalyzes Spd to Put, and also utilizes Spm, T-Spm, and Nor-Spm as substrates in vivo. The OsPAO4 and OsPAO5 proteins prefer to use Spm and T-Spm as substrates, but cannot oxidize Spd to Put, as shown in Table 2 [46,47]. The results suggested that OsPAO3 catalyzes a full BC-type pathway, while OsPAO4 and OsPAO5 only catalyze a partial BC-type pathway, as shown in Table $2[46,47]$. Besides, we found that OsPAO1, localized to the cytoplasm of onion epidermal cells, prefers to use Spm and T-Spm as substrates, and oxidizes these substrates to Spd but not to Put, as shown in Table 2 [46,48]. OsPAO1 and AtPAO5, both of which lack of intron, share high identity at the amino acid levels and exhibit quite similar predicted protein tertiary structures [50]. When the full length cDNA of OsPAO1 was fused to a constitutive promoter and subsequently transformed into the loss-of-function mutant Atpao5-2, the transgenic plants restored normal T-Spm sensitivity, which can grow in the presence of low levels of T-Spm; whereas the control with the introduction of OsPAO3-a peroxisome localized PAO-into Atpao5-2 mutants did not complement the phenotype [50]. These genetic evidences indicated that OsPAO1 and AtPAO5 are functionally orthologous genes in Arabidopsis and rice [50].

Interestingly, our group found that OsPAO7, with high amino acid identity and very similarly predicted protein 3-D structures to ZmPAO1, which is the best characterized maize PAO catalyzed TC-type reaction, is subcellularly localized to the apoplastic space with the aid of a signal peptides (SPs, amino acid position 1-19) and transmembrane domains (TDs, amino acid position 20-29) in its N-terminal, as shown in Table 2 [46,49]. The recombinant OsPAO7 produces 1,3-diaminopropane from both Spd and Spm, indicating that OsPAO7 is the first TC-type enzyme in rice, as shown in Table $2[46,49]$. The observation of OsPAO7 pro:GFP transgenic rice plants showed that OsPAO7 is specifically expressed in anther walls and pollens with an expressional peak at the bicellular pollen stages, as shown in Table $2[46,49]$. Such results suggest that OsPAO7 might have special roles in floral differentiation, especially in anther development and fertility, as shown in Table 2. Recently, Sagor et al. reported that the DNA sequence of the presumed coding region (accession number NM_001069545) for OsPAO6 obtained from the National Center for Biotechnology Information (NCBI) public database is incorrect [60]. They successfully cloned the correct full-length cDNA of 1742 bp (accession number XM_015755533) by rapid amplification of the cDNA ends (RACE) in the $5^{\prime}$-end using 5'-RACE [60]. The correct OsPAO6, encoding a 497-amino acid protein, shows 92\% identity and very similar protein tertiary structures to OSPAO7, and it is subcellularly localized to the plasma membrane, suggesting that OsPAO6 possibly also acts like OsPAO7 having the TC-type activity $[46,49,60]$. Furthermore, OsPAO6 was induced by exogenous jasmonic acid, implying OsPAO6 may be involved in stress tolerance [60]. The last rice PAO, OsPAO2, might have no enzyme activity due to a long truncation at the amino terminal $[46,49,60]$. However, we could not rule out the possibility that the cDNA sequence of OsPAO2 derived from NCBI might be incorrect like the case of OsPAO7.

Up to now, the knowledge of the biological functions of OsPAOs remains limited. Chen et al. found that OsPAO1 7 is most important for rice germination compared to the subfamilies' members OsPAO8 11 encoding histone lysine-specific demethylases, especially OsPAO5 which probably regulates rice seed germination via PAO-generated $\mathrm{H}_{2} \mathrm{O}_{2}$ signaling to mediate coleorhiza-limited rice seed germination [65]. 
Table 2. Summary of PAOs in rice, Arabidopsis, and tomato.

\begin{tabular}{|c|c|c|c|c|c|c|c|}
\hline Gene Name & Gene ID & $\begin{array}{l}\text { Subcellular } \\
\text { Localization }\end{array}$ & $\begin{array}{l}\text { Substrate } \\
\text { Specificity }\end{array}$ & $\begin{array}{l}\text { Mode of } \\
\text { Reaction }\end{array}$ & Tissue Expression & Functions (or Potential Functions) & Reference \\
\hline \multicolumn{8}{|c|}{ Oryza sativa } \\
\hline OsPAO1 & Os01g0710200 & cytoplasm & Spm, T-Spm & $\mathrm{BC}$ & rachis & $\begin{array}{l}\text { rachis development, tolerances, seed } \\
\text { germination }\end{array}$ & {$[31,46-48]$} \\
\hline OsPAO2 & Os03g0193400 & n.d. & n.d. & n.d. & root (with very low expression levels) & tolerances, seed germination & {$[31,46,49]$} \\
\hline OsPAO3 & Os04g0623300 & peroxisome & Spd, Spm, T-Spm & $\mathrm{BC}$ & $\begin{array}{l}\text { All stages. Strongest expressed in leaf, } \\
\text { rachis, node, lower leaf blade, mature } \\
\text { floral organ }\end{array}$ & $\begin{array}{c}\text { leaf and node development, floral } \\
\text { development, fertility, } \\
\text { seed germination }\end{array}$ & {$[31,46,47]$} \\
\hline OsPAO4 & Os04g0671200 & peroxisome & Spm, T-Spm & $\mathrm{BC}$ & rachis, mature floral organ & $\begin{array}{l}\text { rachis and floral development, } \\
\text { fertility, seed germination }\end{array}$ & {$[31,46,47]$} \\
\hline OsPAO5 & Os04g0671300 & peroxisome & Spm, T-Spm & $\mathrm{BC}$ & $\begin{array}{l}\text { flag leaf, lower leaf blade, leaf sheath, } \\
\text { mature floral organ }\end{array}$ & $\begin{array}{l}\text { development of leaf and flower, } \\
\text { fertility, seed germination }\end{array}$ & {$[31,46,47]$} \\
\hline OsPAO6 & Os09g0368200 & apoplast & n.d. & $\mathrm{TC}(?)$ & expressed at negligible levels & tolerances, seed germination & {$[31,46,60]$} \\
\hline OsPAO7 & Os09g0368500 & apoplast & Spm, Spd & TC & anther, pollen & $\begin{array}{l}\text { floral development, fertility, } \\
\text { seed germination }\end{array}$ & {$[31,46,49]$} \\
\hline \multicolumn{8}{|c|}{ Arabidopsis thaliana } \\
\hline AtPAO1 & At5g13700 & cytoplasm & Spm, T-Spm & $\mathrm{BC}$ & root transition region, anther & $\begin{array}{l}\text { stress tolerance, root development, } \\
\text { fertility }\end{array}$ & {$[39,46,61,62,65]$} \\
\hline AtPAO2 & At2g43020 & peroxisome & Spd, Spm, T-Spm & $\mathrm{BC}$ & $\begin{array}{l}\text { root meristem, anther, main vein of } \\
\text { rosette leaf }\end{array}$ & $\begin{array}{l}\text { root development, fertility, vein } \\
\text { development of leaf }\end{array}$ & {$[46,61,62,64,65]$} \\
\hline AtPAO3 & At3g59050 & peroxisome & Spd, Spm, T-Spm & BC & $\begin{array}{l}\text { All stages. Strongest expressed in root } \\
\text { tip, flower, guard cell }\end{array}$ & root and leaf development, fertility & {$[12,46,61,62,65]$} \\
\hline AtPAO4 & At1g65840 & peroxisome & Spm, T-Spm & $\mathrm{BC}$ & $\begin{array}{l}\text { All stages. Strongest expressed in root } \\
\text { and floral organ }\end{array}$ & $\begin{array}{l}\text { Delay dark-induced senescence. Root } \\
\text { development, fertility }\end{array}$ & {$[46,61,62,64-66]$} \\
\hline AtPAO5 & At4g29720 & cytoplasm & Spm, T-Spm & $\mathrm{BC}$ & $\begin{array}{l}\text { All stages. Strongest expressed in mature } \\
\text { leaf, vascular tissue, flower, stem }\end{array}$ & $\begin{array}{l}\text { xylem differentiation, stem } \\
\text { elongation, development of rosette } \\
\text { leaves and vein, tolerance }\end{array}$ & {$[46,51,61,62,65,67-69]$} \\
\hline
\end{tabular}


Table 2. Cont.

\begin{tabular}{|c|c|c|c|c|c|c|c|}
\hline Gene Name & Gene ID & $\begin{array}{l}\text { Subcellular } \\
\text { Localization }\end{array}$ & $\begin{array}{l}\text { Substrate } \\
\text { Specificity }\end{array}$ & $\begin{array}{l}\text { Mode of } \\
\text { Reaction }\end{array}$ & Tissue Expression & Functions (or Potential Functions) & Reference \\
\hline \multicolumn{8}{|c|}{ Solanum lycopersicum } \\
\hline SIPAO1 & Solyc01g087590 & n.d. & n.d. & n.d. & root, stem, leaf of seedling stage & vegetative growth & [63] \\
\hline SIPAO2 & Solyc07g043590 & peroxisome (?) & n.d. & n.d. & $\begin{array}{l}\text { All stages. Strongest expressed in anther, } \\
\qquad \mathrm{Br}, \mathrm{Br}+2 \text {, stem }\end{array}$ & floral development, fruit maturity & [63] \\
\hline SIPAO3 & Solyc12g006370 & peroxisome (?) & n.d. & n.d. & $\begin{array}{l}\text { All stages. Strongest expressed in anther, } \\
\qquad \mathrm{Br}, \mathrm{Br}+2 \text {, leaf }\end{array}$ & floral development, fruit maturity & [63] \\
\hline SIPAO4 & Solyc02g081390 & peroxisome (?) & n.d. & n.d. & $\begin{array}{l}\text { All stages. Strongest expressed in anther, } \\
\qquad \mathrm{Br}, \mathrm{Br}+2, \mathrm{Br}+7 \text {, root, leaf }\end{array}$ & floral development, fruit maturity & [63] \\
\hline SIPAO5 & Solyc03g031880 & peroxisome (?) & n.d. & n.d. & $\begin{array}{c}\text { All stages. Strongest expressed in anther, } \\
\text { leaf, stem }\end{array}$ & floral development & [63] \\
\hline SIPAO6 & Solyc07g039310 & n.d. & n.d. & n.d. & root, stem of seedling stage & vegetative growth & [63] \\
\hline SlPAO7 & Solyc05g018880 & n.d. & n.d. & n.d. & root, stem of seedling stage & vegetative growth & [63] \\
\hline \multicolumn{8}{|c|}{ Brachypodium distachyon } \\
\hline BdPAO1 & XM_003573843 & n.d. & n.d. & n.d. & expressed at very low levels & unknown & [70] \\
\hline BdPAO2 & XM_010242147 & peroxisome (?) & $\begin{array}{c}\text { Spd, Spm, } \\
\text { T-Spm, Nor-Spm, } \\
\text { Nor-Spd }\end{array}$ & $\mathrm{BC}$ & $\begin{array}{l}\text { All stages. Highly expressed in leaf, } \\
\text { stem, and inflorescence }\end{array}$ & $\begin{array}{l}\text { development of stem and } \\
\text { inflorescence }\end{array}$ & [70] \\
\hline BdPAO3 & XM_003580746 & n.d. & Spm, & $\mathrm{BC}$ & leaf, stem, and inflorescence & $\begin{array}{l}\text { development of stem and } \\
\text { inflorescence }\end{array}$ & [70] \\
\hline BdPAO4 & XM_003580747 & peroxisome (?) & n.d. & n.d. & leaf, stem, and inflorescence & $\begin{array}{l}\text { development of stem and } \\
\text { inflorescence }\end{array}$ & [70] \\
\hline BdPAO5 & XM_003566997 & n.d. & n.d. & n.d. & expressed at very low levels & unknown & [70] \\
\hline \multicolumn{8}{|c|}{ Citrus sinensis } \\
\hline CsPAO1 & Cs7g02060.1 & n.d. & n.d. & BC (?) & leaf, stem, root, cotyledon & root growth, vegetative growth & {$[55,71]$} \\
\hline CsPAO2 & Cs7g18840.2 & peroxisome (?) & n.d. & BC (?) & leaf, stem, root, cotyledon & root growth, vegetative growth & {$[55,71]$} \\
\hline CsPAO3 & Cs6g15870.1 & peroxisome (?) & n.d. & BC (?) & leaf, stem, root, cotyledon & root growth, vegetative growth & {$[55,71]$} \\
\hline CsPAO4 & Cs4g14150.1 & apoplast & Spd, Spm & $\mathrm{TC}$ & leaf, stem, root & $\begin{array}{l}\text { seed germination, the growth of root } \\
\text { and vegetative, salt tolerance }\end{array}$ & {$[55,71]$} \\
\hline CsPAO5 & Cs7g23790.1 & n.d. & n.d. & BC (?) & leaf, stem, root, cotyledon & root growth, vegetative growth & {$[55,71]$} \\
\hline CsPAO6 & Cs7g23760.1 & n.d. & n.d. & BC (?) & stem, root, cotyledon & root growth, vegetative growth & {$[55,71]$} \\
\hline
\end{tabular}

n. d., not determined; Br, breaker stage fruit; $\mathrm{Br}+2$, two days post breaker stage fruit; $\mathrm{Br}+7$, seven days post breaker stage fruit; $\mathrm{BC}$, back conversion; $\mathrm{TC}$, terminal catabolism. 
Above all, two different kinds of PAOs exist in rice; one is BC-type (OsPAO1, OsPAO3 5), the other is TC-type (OsPAO7, and OsPAO6 possibly also has this activity), as shown in Table $2[46,49,60]$. To fully understand the biological functions of OsPAOs in various developmental and physiological processes, molecular and genetic approaches like CRISPR/Cas9-mediated loss-of-function mutants and ubiquitin promoter enhanced overexpression transgenic plants should be generated.

\subsection{Arabidopsis PAOs}

The Arabidopsis genome contains five PAOs, named as AtPAO1 to AtPAO5. The recombinant protein of the former four AtPAOs, AtPAO1 4, have been homogenously purified and characterized $[12,39,61,62,64,65]$; besides, AtPAO5 also has been purified and biochemically characterized [46,51]. In detail, AtPAO1, subcellularly localized in cytoplasm, catalyzes a BC-type reaction, and prefers to utilize Spm, T-Spm, and NorSpm as substrates [39]; AtPAO2 4, localized to peroxisomes, all display a BC-type reaction with different substrate specificity $[12,61,62,64]$. AtPAO2 3 oxidize Spm to Put in a full BC-type reaction via Spd, whereas the other peroxisomal AtPAO4 mainly catalyzes the partial BC-type because only very few Put can be detected when Spm was used as the substrate [61].

Five Arabidopsis PAOs showed different expression patterns. AtPAO1 is specifically expressed in the root transition region (between the meristematic and elongation zones of the root) and anther tapetum [65], and Takahashi et al. also found that AtPAO1 is specifically expressed in anthers [62]. AtPAO1 was reported to be involved in environment stress tolerance $[39,65]$, and the expression patterns imply AtPAO1 may also play roles in root development and fertility, as shown in Table 2 [62]. AtPAO2 is mainly expressed in the root and shoot meristematic area, the vein of rosette leaves, as well as the anthers, suggesting that AtPAO2 might function in the development of roots, shoots, leaves, and flowers, as shown in Table 2 [62]. AtPAO3 and AtPAO4 display similar expression patterns, which are expressed in all tissues and whole growth stages, especially in roots, leaves, and flowers, suggesting that these two members may mediate various significant growth processes, as shown in Table 2 [62]. pao4-1 and pao4-2, two independent lines of AtPAO4 loss-of-function mutants, have 10-fold higher Spm levels compared to wild type, and delay dark-triggered senescence [66]. The last Arabidopsis PAO, AtPAO5, is expressed in all developmental stages, with strongest expression in roots, stems, leaves, and floral organs, as shown in Table $2[51,62]$.

AtPAO5 is a relatively completely explained Arabidopsis PAO, and its gene product AtPAO5 has been successfully characterized and its biological function also has been explored $[51,67,68]$. AtPAO5 can catalyze both Spm and T-Spm to Spd, but not to Put [51]. Our former colleagues Kim et al. reported that AtPAO5 regulates stem elongation and the rosette leaves' development, as shown in Table 2 [51,62]. Two AtPAO5 T-DNA insertion mutants, pao5-1 and pao5-2, both of which show about 2-fold higher levels of T-Spm, still maintain normal levels of Put, Spd, and Spm compared to the wild type controls [51]. The pao5-1 and pao5-2 mutants exhibit more rosette leaves, and shorter and fewer inflorescence stems at the two-month-old stage. Further genetic and morphology analysis suggested that AtPAO5 plays roles in Arabidopsis growth and development through oxidizing T-Spm [46,51]. Ahou et al. found that AtPAO5 functions as an SMO/dehydrogenase [69]. atpao5-2 and atpao5-3, two independent loss-of-function mutants of AtPAO5, show higher T-Spm contents, mediate metabolic and transcriptional reprogramming, and enhance salt-related stress tolerance [67]. AtPAO5 also plays roles in the control of proper xylem differentiation through interplaying between auxin and cytokinins [68]. Above all, the AtPAO5 mutant with higher T-Spm levels shows the similar phenotypes as acl5 (tkv) and bud2 mutants, which only contain very low or even zero T-Spm content $[7,9,15,62,72,73]$. These results explained that maintaining suitable T-Spm content is very important in plants.

Taken together, all five Arabidopsis PAOs catalyze BC-type reactions and mediate (or potentially mediate) the entire developmental processes in plants, as shown in Figure 2 and Table 2 [46], and their (especially the AtPAO1 4) biological functions need to be further unveiled in the future. 


\subsection{Tomato PAOs}

Transgenic tomato plants overexpressing maize PAO (MPAO) exhibit tissue damage with lower chlorophyll content, lower photochemical efficiency of photosystem II (PSII), and DNA fragmentation compared to wild type, suggesting that the increased PAO activity cannot cope with the reactive oxygen species (ROS) generated by environmental factors [13]. In S. lycopersicum cv. Chiou, the expression of PAO peaked at ImG1 (fruits $0.5 \mathrm{~cm}$ in diameter) and ImG2 (fruits $1 \mathrm{~cm}$ in diameter) stages, suggesting PAO participates in developmental processes of the fruits, including the cell wall maturation [74]. Gémes et al. reported that sense-ZmPAO (S-ZmPAO) transgenic tomato plants have slightly larger leaf sizes and higher antioxidant enzyme activities; in contrast, the antisense-ZmPAO $(A S-Z m P A O)$ transgenic tomato plants contain lower chlorophyll content index, smaller leaves, and less biomass, as well as an increment in $\mathrm{Ca}^{2+}$ when responding to salt stress [29]. The phenotypes of S-ZmPAO and AS-ZmPAO transgenic plants suggested that apoplastic PAO play important roles in plant growth and stress responses [29]. Most recently, we found that the model dicotyledons of the tomato plant (Solanum lycopersicum) has seven $P A O$ genes in its genome, which were orderly named as SIPAO1 to SIPAO7 [63]. SIPAO2 5, sharing high identity (over 64\%) of amino acid and showing quite similar genome organization and predicted tertiary structures, have similar tissue expression patterns [63]. Besides, SIPAO2 4 are ubiquitously and highly expressed in the whole growth processes and all tissues, predominantly in anther, $\mathrm{Br}$ (breaker stage fruit), and $\mathrm{Br}+2$ (two days post breaker stage fruit) [63], suggesting that SIPAO2 4 may play dominant roles in all stages of growth especially in floral development and fruit maturity in tomato, as shown in Table 2 [63]. SIPAO1 is expressed relatively lower than SIPAO2 4 in all of the vegetative tissues and anthers [63]. What is more, SIPAO6 7, sharing quite similar identity of amino acid and very similar intron-exon organization and protein 3-D structures, are lowly expressed in vegetative and reproductive tissues, but had relatively higher expression in roots, stems, buds, and anthers than in the fruit [63], suggesting that these two tomato PAOs may mainly function in vegetative and anthesis tissues but not in fruit, as shown in Table 2. SIPAOs respond to abiotic stresses (heat, wound, cold, drought, and salt), oxygen species $\left(\mathrm{H}_{2} \mathrm{O}_{2}\right.$ and methylviologen), phytohormones (IAA, 6-BA, GA, ABA, Eth, SA, and JA), as well as PAs (Put, Spd, Spm, and T-Spm), implying that tomato PAOs possibly have various functions in stress tolerances, as shown in Table 2 [63]. Taken together, SIPAOs possibly play vital roles in different tissues and developmental stages, especially in floral development and fruit repining. To better explain the mechanism of polyamine catabolism and biological roles of SIPAOs, more biochemical and genetic experiments are required.

\subsection{PAOs in Other Plants}

Recently, besides these three model plants (rice, Arabidopsis, and tomato), some other plant species have also been studied on PAO catabolism, and PAO biological functions. Plant PAOs play important roles in various stress tolerance and the programmed cell death (PCD) events through mediating $\mathrm{H}_{2} \mathrm{O}_{2}$ signaling which is generated by stress-induced $\mathrm{PAO}$ activity leading to Spd, Spm, and T-Spm oxidation [13,33,75-98]. Hatmi et al. reported that the grapevine PAO and CuAO activities were upregulated by osmotic stress and Botrytis cinerea infection, suggesting that PA back-conversion and/or terminal catabolism were involved in PA homeostasis under stress conditions [97]. In addition, the PAO activity increment and proline accumulation were involved in cold tolerance in Medicago falcate [75,76], suggesting that PAOs and proline interplay in the process of various stress responses [75,76,99-101]. What is more, in salinity tolerance 1 (st1), a wheat salinity-tolerant line, the expression of $P A O$ genes showed high expression levels, suggesting that $P A O$ genes may have important functions in salinity tolerance [102].

Previously, Sagor and his colleagues reported that SelPAO5 from Selaginella lepidophylla back-converts Spm and T-Spm to Spd and Nor-Spd, respectively [53]. It is different from AtPAO5 and OsPAO1 which prefer to use the same substrates as SelPAO5, but both of these two enzymes convert the substrates to Spd, though three of them are from the same clade in the phylogenic 
relationship tree, suggesting that SelPAO5 oxidizes T-Spm at different carbon positions [53]. Most recently, they further found that the SelPAO5 can complement the dwarf phenotype of Atpao5, with the reduction of T-Spm content to almost normal levels of wild type, which strengthens the claim that T-Spm homeostasis is required for plant development and growth [103]. Besides, Wang and Liu firstly identified PAOs from sweet orange (Citrus sinensis); their results indicated that six PAO genes (CsPAO1-CsPAO6) exist in sweet orange, and they also found that CsPAO3 may have potential roles in PA back conversion in plants, while CsPAO4 catalyzes Spd and Spm as substrates for terminal catabolism [55,71]. The transgenic plants overexpressing CsPAO4 showed growth inhibition under salt stress caused by the elevation of $\mathrm{H}_{2} \mathrm{O}_{2}$ which leads to oxidative damages [55]. What is more, Brikis et al. found that the expression of $\mathrm{MdPAO} 2$ was obviously upregulated in apple fruit by elevating the $\mathrm{CO}_{2}$ concentrations under low-temperature/low- $\mathrm{O}_{2}$ storage for up to sixteen weeks, suggesting that $M d P A O 2$ is involved in respiratory activities in apple fruit storage under multiple abiotic stresses [104]. Furthermore, Takahashi et al. characterized the molecular and biochemical features of five PAOs (BdPAO1 to BdPAO5) from Brachypodium distachyon, and they found that BdPAO2 and BdPAO4 possibly are localized to peroxisomes [70]. Additionally, they also found that BdPAO2 catalyzes a full-back conversion pathway, and the favorite substrates of $\mathrm{BdPAO} 2$ and $\mathrm{BdPAO} 3$ are Spd and Spm, respectively [70].

Plant PAOs play significant roles in metal toxicity tolerance. Aluminum (Al), copper $(\mathrm{Cu})$, and cadmium (Cd), etc. are phytotoxic to plants at high concentrations $[33,81,97,105,106]$. In wheat, the cell wall-bound PAO (CW-PAO) oxidized Spd and generated $\mathrm{H}_{2} \mathrm{O}_{2}$ under Al toxicity; in contrast, the CW-PAO activity was markedly inhibited by Put application, and subsequently reduced $\mathrm{H}_{2} \mathrm{O}_{2}$ accumulation in roots under $\mathrm{Al}$ stress, suggesting that Put plays an important protective role against Al-induced oxidative stress via inhibiting the $\mathrm{PAO}$ activity with lower $\mathrm{H}_{2} \mathrm{O}_{2}$ production [33]. Similarly, the PAO activity was enhanced by higher $\mathrm{Cu}$ or $\mathrm{Cd}$ concentrations leading to accelerating the PA back-conversion or terminal catabolism, which may be related to functionality of defense mechanisms $[105,106]$. To entirely understand the functional mechanism of PAOs on metal toxicity tolerance, more attractive and systematic studies are required.

Plant PAOs have important roles in plant growth and development. Around fifteen years ago, the functions of the maize PAO were investigated by the Rea group and the Cona group separately, and they found that the maize PAO plays roles in cell-wall maturation and root differentiation by producing $\mathrm{H}_{2} \mathrm{O}_{2}[107,108]$. Gomez-Jimenez et al. reported that PAO and DAO have significant functions in olive fruit abscission zone (AZ) development through providing apoplastic $\mathrm{H}_{2} \mathrm{O}_{2}$ for cell-wall strengthening and lignosuberization events, and the peroxidase substrate is provided in these cells throughout AZ development [109]. Moreover, Rodríguez et al. reported that the increased PAO activity produces more $\mathrm{H}_{2} \mathrm{O}_{2}$ to generate $\cdot \mathrm{O}^{2-}$ through enhanced substrate availability and subsequently maintain maize leaf elongation under saline stress [16]. What is more, the tomato PAO is involved in vascular development via mediating $\mathrm{H}_{2} \mathrm{O}_{2}$ which is required by vascular differentiation and the process of polymerization of lignin precursors into lignin [110]. Atpao3, a loss-of-function mutant of AtPAO3 which oxidizes Spd in peroxisomes [12], shows reduced pollen tube and seed setting caused by significantly disrupted Spd-induced $\mathrm{Ca}^{2+}$ currents [111]. Furthermore, Agudelo-Romero et al. found that the activities of PAO and DAO are significantly increased during grape ripening, implying an important role of polyamines' catabolism in fruit ripening [112].

\subsection{Peroxisomal PAOs in Plants}

In Arabidopsis, AtPAO2 4 were speculated to be localized to peroxisomes [12,39,62,64,65]; additionally, in rice, we also found that OsPAO3 5 are situated in peroxisomes [46,47]. Besides, recently some other groups reported that BdPAO2 and BdPAO4 from Brachypodium distachyon [70], BrPAO2 4 from Brassica rapa [81], CsPAO2 3 from Citrus sinensis [71], and SIPAO2 4 from tomato [63] were predicted to be peroxisomal PAOs. All of these genes' products classifying into clade IV, as shown in Figure 2, contain peroxisomal-targeting signals in their C-terminal, resulting in localization to 
peroxisome, as shown in Figure $3[12,39,46,47,62-65,70,81]$. In the apple genome, six putative apple PAO genes were identified [104]. The MdPAO2 4 were predicted to localize in peroxisomes, whereas MdPAO1 and MdPAO5 6 were predicted to be cytosolic proteins [104]. In addition, four CuAO-like genes from Arabidopsis have two different localizations; the $\mathrm{AtCuAO} 2$ and $\mathrm{AtCuAO} 3$ are localized to peroxisomes, while the AtAO1 and AtCuAO1 are localized to apoplast [113].

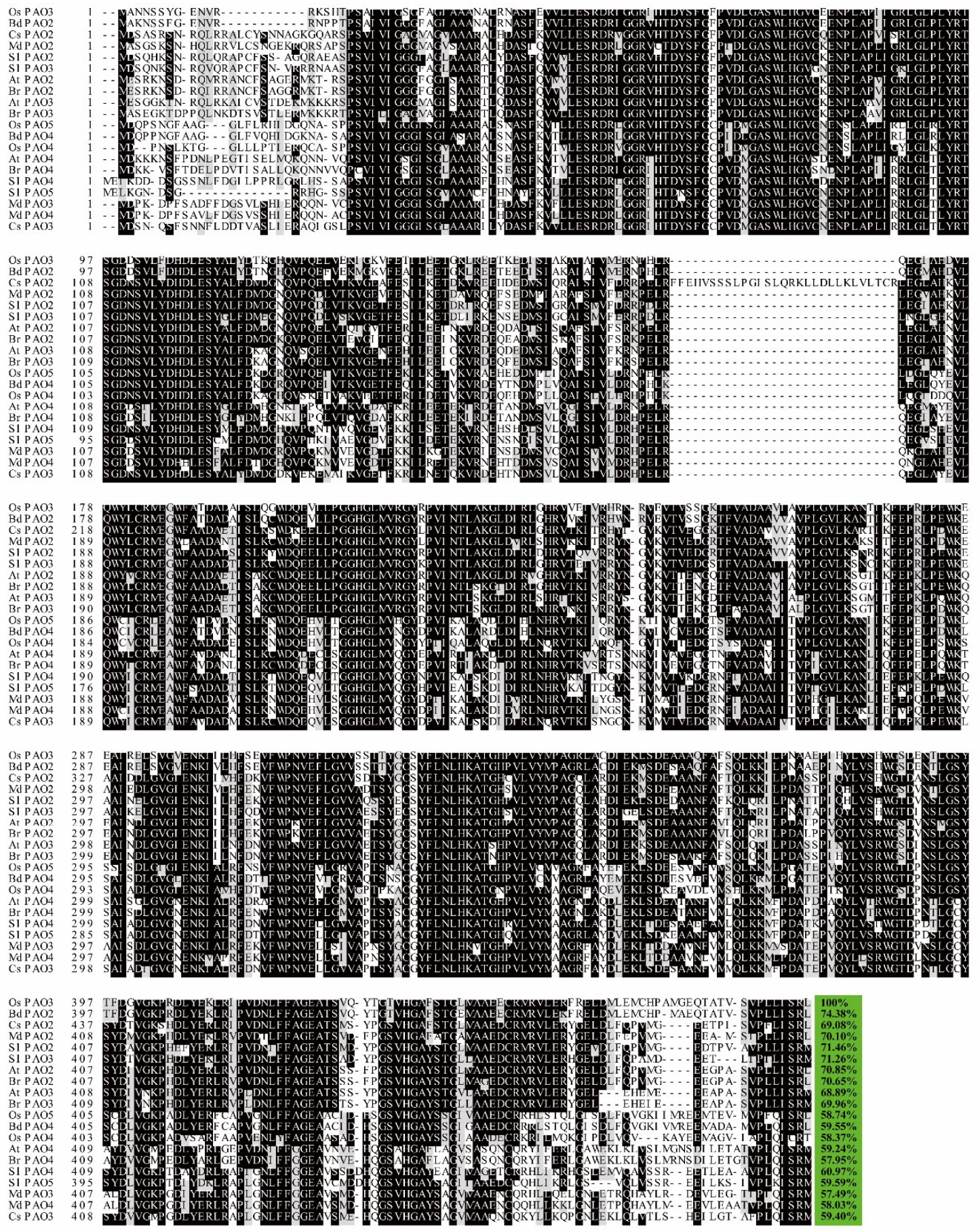

Figure 3. Alignment of amino acid sequences of twenty reported peroxisomal PAOs from Oryza sativa, Arabidopsis thaliana, Solanum lycopersicum, Brachypodium distachyon, Brassica rapa, Citrus sinensis, and Malus domestica. The alignment was performed by the Clustal X 1.83 software and exhibited by the Boxshade program (http://www.ch.embnet.org/software/BOX_form.html.). Black and gray indicate the complete and partial homology of the amino acid sequences, respectively. The percentages at the end of the alignment showed the identity between OsPAO3 and other PAOs. 
These peroxisomal PAOs shared high identity (over 57\% compared to OsPAO3 which was set as $100 \%$ ), as shown in Figure 3, and displayed quite similar predicted protein tertiary structures, as shown in Figure 4A-Q, even though these PAOs are from six different species. Interestingly, the predicted protein tertiary structures of these twenty peroxisomal PAOs almost fully merged with each other, as shown in Figure $4 \mathrm{U}$, except OsPAO4 and CsPAO2 that cannot merge with other PAOs; whereas, to our surprise, the OsPAO4 and CsPAO2 were largely merged, as shown in Figure $4 \mathrm{~V}$. Besides, the protein sequence of $\mathrm{CsPAO} 2$ contains an additional twenty-nine amino acid sequence in the conserved region compared to other peroxisomal PAOs, as shown in Figure 3, that may be because of the mRNA alternative splicing, though the possible function of this additional sequence remains totally unknown. The results of phylogenetic relationship analysis, as shown in Figure 4W, also indicated that these peroxisomal PAOs are highly conserved and extremely close during evolution in the plant kingdom.
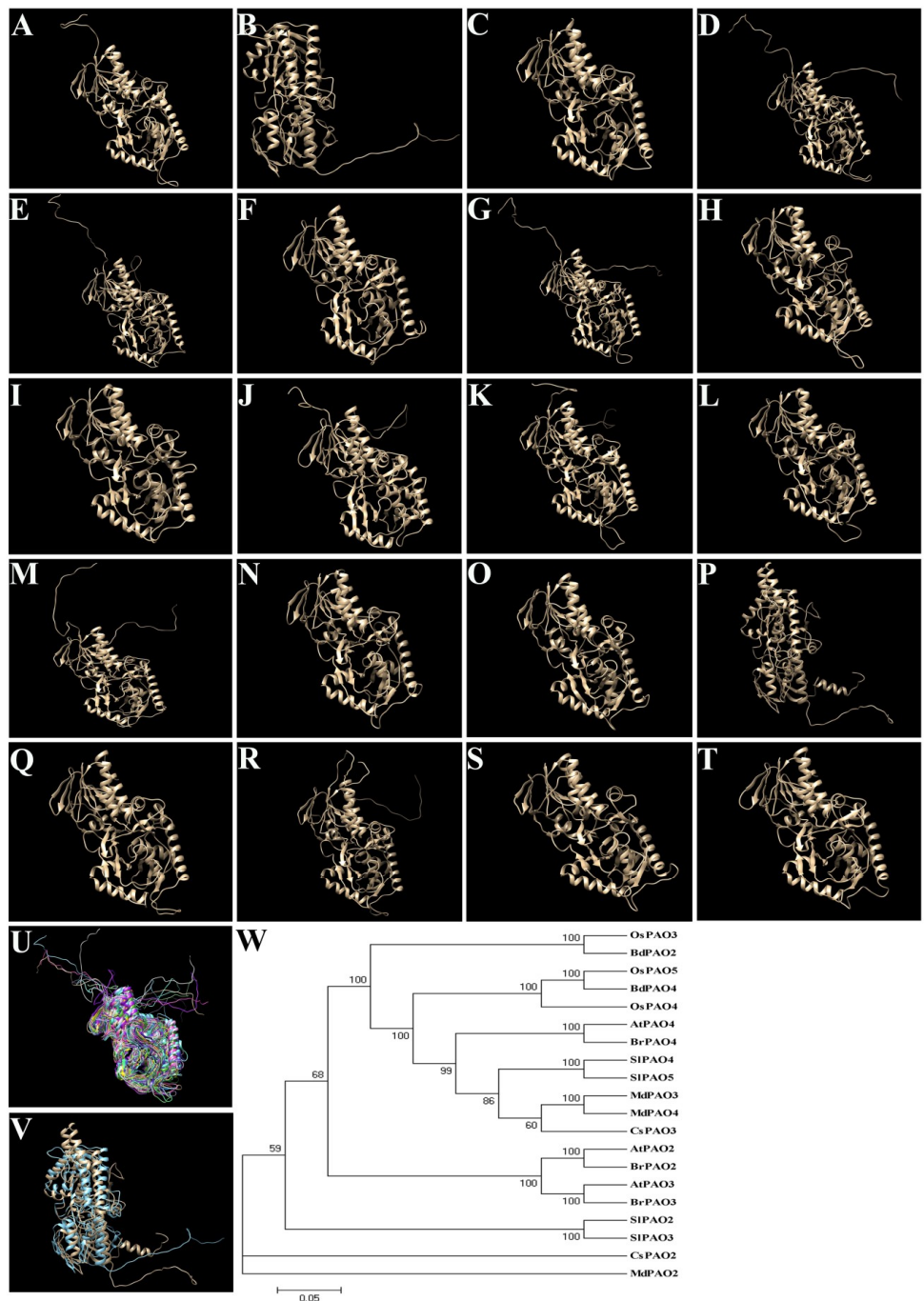

Figure 4. Predicted tertiary structures of the reported peroxisomal PAOs. Twenty have been reported; peroxisomal plant PAOs were analyzed. (A-J), The protein 3-D structures of OsPAO3 (A); OsPAO4 (B); OsPAO5 (C); AtPAO2 (D); AtPAO3 (E); AtPAO5 (F); SIPAO2 (G); SIPAO3 (H); SIPAO4 (I); SIPAO5 (J); BdPAO2 (K); BdPAO4 (L); BrPAO2 (M); BrPAO3 (N); BrPAO4 (O); CsPAO2 (P); CsPAO3 (Q); MdPAO2 (R); MdPAO3 (S); and MdPAO4 (T) were obtained using the Protein Structure Prediction Server program (http://ps2v3.life.nctu.edu.tw/) and Chimera 1.13 software. (U) Merged image of all PAOs, except OsPAO4 and CsPAO2, was performed by Chimera 1.13 software. (V) Merged image of OsPAO4 and $\mathrm{CsPAO} 2$ was similarly performed. The light blue and light yellow colors indicate the protein structures of OsPAO4 and CsPAO2, respectively. (W) Evolution relationship among the peroxisomal PAOs. 
It is suggested that the peroxisomal PAOs possibly play significant roles in plant growth processes, especially in floral development, as shown in Table 2. To explore the physiological and biological significance of peroxisomal PAOs, genetic and morphological approaches are required via generating functional knock-down (or knock-out) mutants. Besides, apoplastic PAOs were found in monocotyledonous plants such as maize PAO (ZmPAO), barley PAO (HvPAOs), and rice PAO (OsPAOs), which were involved in TC-type pathways to catalyze PA terminal oxidation [36,42,44-46,49,60,107]. In dicots, apoplastic PAOs may be present in limited species [55]. What is more, the cytoplasmic PAOs were characterized in Arabidopsis (AtPAO1 and AtPAO5) [39,51,61,62,65] and rice (OsPAO1) $[46,48]$, which catalyzed PA back conversion reactions. However, the roles of the three types of PAOs in plant growth and development, and stress tolerance through PA homeostasis and/or $\mathrm{H}_{2} \mathrm{O}_{2}$ generation, remain fragmentary. Thereby, the significance of the functional difference between peroxisomal or cytoplasmic PAOs and apoplastic PAOs remains to be clarified and should be addressed in future work.

\section{Conclusions and Future Perspective of PAOs Research in Plants}

In the past years, some PAO genes were cloned and functionally identified from different plant species. Some research groups focus on the PA catabolism pathway, meanwhile, more and more researchers pay intense attention to the biological roles of PAOs. As it is known, when plants grow under normal conditions, the intracellular PAs maintain homeostasis, and the normal level of $\mathrm{H}_{2} \mathrm{O}_{2}$ is generated by PAOs. Subsequently the $\mathrm{H}_{2} \mathrm{O}_{2}$ signal participates in the developmental processes such as root growth, xylem differentiation, pollen tube growth, fruit development, etc., as shown in Figure $5[65,69,99,111,112]$. However, the PAs homeostasis might encounter challenges under stress conditions. The enhanced accumulation of stress-induced PAs requires higher PAO activity to rebalance the PAs homeostasis. If just under mild stress, the plants can overcome the unpleasant period via the antioxidant reaction with the aid of proline and other catabolites that were also induced by stress [76,99-101]. If under severe stress and longtime stress conditions, the PAO activity markedly increases to reduce the stress-induced intracellular PAs level with high $\mathrm{H}_{2} \mathrm{O}_{2}$ accumulation, leading to a ROS burst which may result in death, as shown in Figure 5. The antioxidant activity cannot offset the strong ROS burst, though the levels of proline and other catabolites are also upregulated by stress, as shown in Figure $5[93,94]$.

Recently, the enzyme features of all the Arabidopsis PAOs and most rice PAOs have been identified, but their biological roles remain largely unclear. Meanwhile, the tomato PAOs have been cloned, but its catabolic activities and biological functions are still unknown. What is more, the exact roles of the highly conserved peroxisomal PAOs in plants are still fuzzy. Furthermore, why does rice have two different types of $P A O$ catabolic pathways (the BC-type and TC-type pathway)? In addition, the exact mechanism of PA metabolism and the PA-cycle-PA exodus-as well as the possible ratio between the back-conversion and terminal catabolism in plants needs to be uncovered. Finally, what is the possible relationship between PAO and proline when plants fight against environmental stresses? To fully understand the roles of PAOs in plant development and stress interactions, intensive studies are required via generating loss-of-function mutants and overexpression transgenic plants which will greatly help further explore the biochemical and physiological roles of these PAOs. 


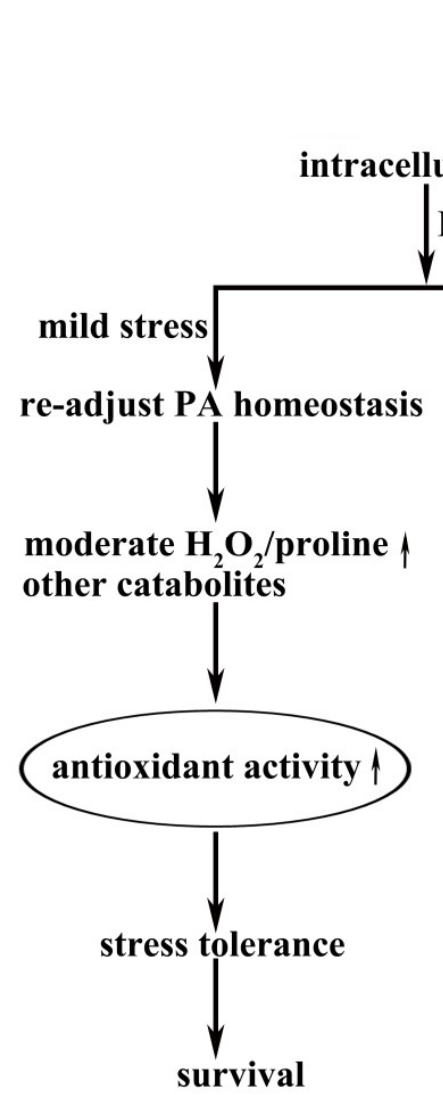

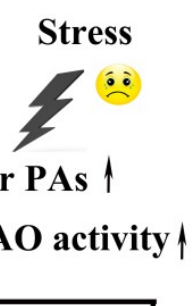

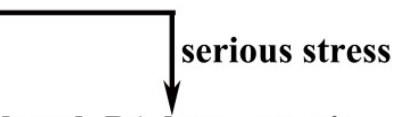

break PA homeostasis

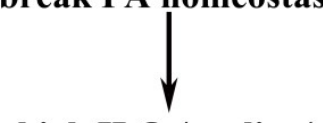

high $\mathrm{H}_{2} \mathrm{O}_{2} /$ proline/ other catabolites

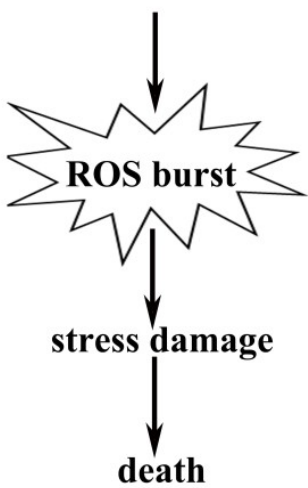

Normal condition

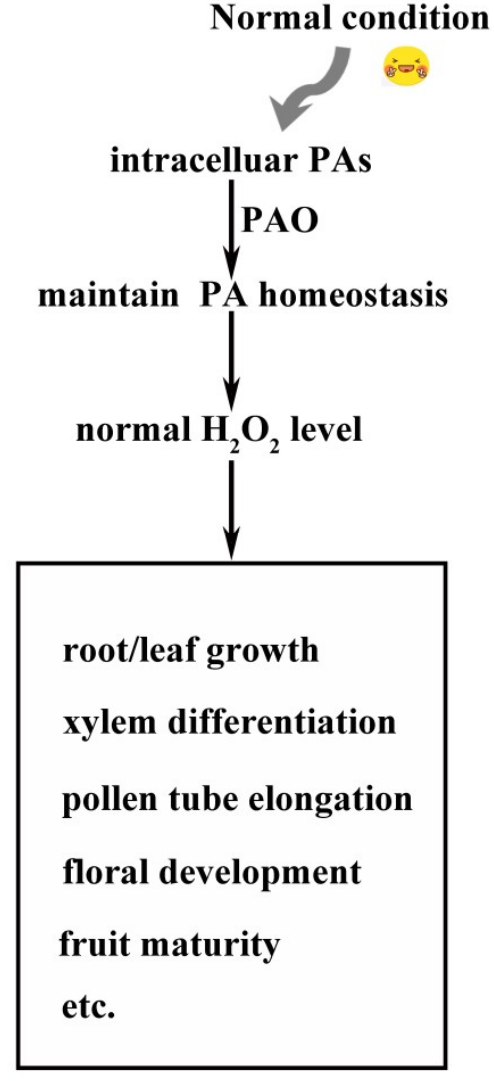

Figure 5. Diagrammatic representation of the roles of PAO involved in developmental growth and environmental stress response in plants. The thick upright arrows indicate increase in the activity or concentrations. The cartoon pictures of smiling and bitter faces indicate the plant growth under normal or stress conditions, respectively. ROS: reactive oxygen species.

Author Contributions: Z.Y. analyzed the data and made the figures; D.J. revised the manuscript; T.L. designed the study, analyzed the data, and wrote the manuscript. All authors read and approved the final manuscript.

Funding: This research was funded by National Natural Science Foundation of China (31600217).

Conflicts of Interest: The authors have no conflicts of interest to declare.

\section{References}

1. Cohen, S.S. A Guide to the Polyamines; Oxford University Press: New York, NY, USA, 1998.

2. Tabor, C.W.; Tabor, H. Polyamines. Annu. Rev. Plant. Biol. 1984, 53, 749-790. [CrossRef] [PubMed]

3. Knott, J.M.; Römer, P.; Sumper, M. Putative spermine synthases from Thalassiosira pseudonana and Arabidopsis thaliana synthesize thermospermine rather than spermine. FEBS Lett. 2007, 581, 3081-3086. [CrossRef] [PubMed]

4. Kusano, T.; Berberich, T.; Tateda, C.; Takahashi, Y. Polyamines, essential factors for growth and survival. Planta 2008, 228, 367-381. [CrossRef] [PubMed]

5. Handa, A.K.; Mattoo, A. Differential and functional interactions emphasize the multiple roles of polyamines in plants. Plant Physiol. Biochem. 2010, 48, 540-546. [CrossRef]

6. Mattoo, A.K.; Minocha, S.C.; Minocha, R.; Handa, A.K. Polyamines and cellular metabolism in plants, transgenic approaches reveal different responses to diamine putrescine versus higher polyamines spermidine and spermine. Amino Acids 2010, 38, 405-413. [CrossRef] [PubMed]

7. Takano, A.; Kakehi, J.; Takahashi, T. Thermospermine is not a minor polyamine in the plant kingdom. Plant Cell Physiol. 2012, 53, 606-616. [CrossRef] [PubMed]

8. Hanzawa, Y.; Takahashi, T.; Komeda, Y. ACL5, an Arabidopsis gene required for internodal elongation after flowering. Plant J. 1997, 12, 863-874. [CrossRef] [PubMed] 
9. Hanzawa, Y.; Takahashi, T.; Michael, A.J.; Burtin, D.; Long, D.; Pineiro, M.; Coupland, G.; Komeda, Y. ACAULIS5, an Arabidopsis gene required for stem elongation, encodes a spermine synthase. EMBO J. 2000, 19, 4248-4256. [CrossRef] [PubMed]

10. Bouchereau, A.; Aziz, A.; Larher, F.; Martin, T.J. Polyamines and environmental challenges, recent development. Plant Sci. 1999, 140, 103-125. [CrossRef]

11. Minocha, R.; Majumdar, R.; Minocha, S.C. Polyamines and abiotic stress in plants: A complex relationship. Front. Plant Sci. 2014, 5, 175. [CrossRef]

12. Moschou, P.N.; Sanmartin, M.; Andriopoulou, A.H.; Rojo, E.; Sanchez-Serrano, J.J.; Roubelakis-Angelakis, K.A. Bridging the gap between plant and mammalian polyamine catabolism, a novel peroxisomal polyamine oxidase responsible for a full back-conversion pathway in Arabidopsis. Plant Physiol. 2008, 147, 1845-1857. [CrossRef] [PubMed]

13. Moschou, P.N.; Paschalidis, K.A.; Delis, I.D.; Andriopoulou, A.H.; Lagiotis, G.D.; Yakoumakis, D.I.; Roubelakis-Angelakis, K.A. Spermidine exodus and oxidation in the apoplast induced by abiotic stress is responsible for $\mathrm{H}_{2} \mathrm{O}_{2}$ signatures that direct tolerance responses in tobacco. Plant Cell. 2008, 20, 1708-1724. [CrossRef] [PubMed]

14. Moschou, P.N.; Roubelakis-Angelakis, K.A. Polyamines and programmed cell death. J. Exp. Bot. 2014, 65, 1285-1296. [CrossRef] [PubMed]

15. Kakehi, J.I.; Kuwashiro, Y.; Niitsu, M.; Takahashi, T. Thermospermine is required for stem elongation in Arabidopsis thaliana. Plant Cell Physiol. 2008, 49, 1342-1349. [CrossRef] [PubMed]

16. Rodriguez, A.A.; Maiale, S.J.; Menendez, A.B.; Ruiz, O.A. Polyamine oxidase activity contributes to sustain maize leaf elongation under saline stress. J. Exp. Bot. 2009, 60, 4249-4262. [CrossRef] [PubMed]

17. Naka, Y.; Watanabe, K.; Sagor, G.H.M.; Niitsu, M.; Pillai, M.A.; Kusano, T.; Takahashi, Y. Quantitative analysis of plant polyamines including thermospermine during growth and salinity stress. Plant Physiol. Biochem. 2010, 48, 527-533. [CrossRef] [PubMed]

18. Groppa, M.D.; Benavides, M.P. Polyamines and abiotic stress, recent advances. Amino Acids 2008, 34, 35-45. [CrossRef] [PubMed]

19. Alcazar, R.; Altabella, T.; Marco, F.; Bortolotti, C.; Reymond, M.; Koncz, C.; Carrasco, P.; Tiburcio, A.F. Polyamines, molecules with regulatory functions in plant abiotic stress tolerance. Planta 2010, 231, 1237-1249. [CrossRef] [PubMed]

20. Marina, M.; Sirera, F.V.; Rambla, J.L.; Gonzalez, M.E.; Blazquez, M.A.; Carbonell, J.; Pieckenstain, F.L.; Ruiz, O.A. Thermospermine catabolism increases Arabidopsis thaliana resistance to Pseudomonas viridiflava. J. Exp. Bot. 2013, 64, 1393-1402. [CrossRef] [PubMed]

21. Hatmi, S.; Gruau, C.; Trotel-Aziz, P.; Villaume, S.; Rabenoelina, F.; Baillieul, F.; Eullaffroy, P.; Clément, C.; Ferchichi, A.; Aziz, A. Drought stress tolerance in grapevine involves activation of polyamine oxidation contributing to improved immune response and low susceptibility to Botrytis cinerea. J. Exp. Bot. 2015, 66, 775-787. [CrossRef] [PubMed]

22. Cai, G.; Sobieszczuk-Nowicka, E.; Aloisi, I.; Fattorini, L.; Serafini-Fracassini, D.; Del Duca, S. Polyamines are common players in different facets of plant programmed cell death. Amino Acids 2015, 47, 27-44. [CrossRef] [PubMed]

23. Liu, J.H.; Wang, W.; Wu, H.; Gong, X.Q.; Moriguchi, T. Polyamines function in stress tolerance, from synthesis to regulation. Front. Plant Sci. 2015, 6, 827. [CrossRef] [PubMed]

24. Huang, X.-S.; Zhang, Q.; Zhu, D.; Fu, X.; Wang, M.; Zhang, Q.; Moriguchi, T.; Liu, J.-H. ICE1 of Poncirus trifoliata functions in cold tolerance by modulating polyamine levels by interacting with arginine decarboxylase. J. Exp. Bot. 2015, 68, 3259-3274. [CrossRef] [PubMed]

25. Ebeed,H.T.; Hassan, N.M.; Aljarani, A.M. Exogenous applications of Polyamines modulate drought responses in wheat through osmolytes accumulation, increasing free polyamine levels and regulation of polyamine biosynthetic genes. Plant Physiol. Biochem. 2017, 118, 438-448. [CrossRef] [PubMed]

26. Yang, W.B.; Li, Y.; Yin, Y.P.; Qin, Z.L.; Zheng, M.J.; Chen, J.; Luo, Y.L.; Pang, D.W.; Jiang, W.W.; Li, Y.; et al. Involvement of ethylene and polyamines biosynthesis and abdominal phloem tissues characters of wheat caryopsis during grain filling under stress conditions. Sci. Rep. 2017, 7, 46020. [CrossRef]

27. Park, J.Y.; Kang, B.R.; Ryu, C.M.; Anderson, A.J.; Kim, Y.C. Polyamine is a critical determinant of Pseudomonas chlororaphis $\mathrm{O} 6$ for GacS-dependent bacterial cell growth and biocontrol capacity. Mol. Plant Pathol. 2018, 19, 1257-1266. [CrossRef] [PubMed] 
28. Wuddineh, W.; Minocha, R.; Minocha, S.C. Polyamines in the Context of Metabolic Networks; Alcázar, R., Tiburcio, A., Eds.; Humana Press: New York, NY, USA, 2018; pp. 1-23.

29. Gémes, K.; Mellidou, I.; Karamanoli, K.; Beris, D.; Park, K.Y.; Matsi, T.; Haralampidis, K.; Constantinidou, H.I.; Roubelakis-Angelakis, K.A. Deregulation of apoplastic polyamine oxidase affects development and salt response of tobacco plants. J. Plant Physiol. 2017, 211, 1-12. [CrossRef] [PubMed]

30. Mellidou, I.; Karamanoli, K.; Beris, D.; Haralampidis, K.; Constantinidou, H.A.; Roubelakis-Angelakis, K.A. Underexpression of apoplastic polyamine oxidase improves thermotolerance in Nicotiana tabacum. J. Plant Physiol. 2017, 218, 171-174. [CrossRef] [PubMed]

31. Chen, B.-X.; Li, W.-Y.; Gao, Y.-T.; Chen, Z.-J.; Zhang, W.-N.; Liu, Q.-J.; Chen, Z. Involvement of polyamine oxidase-produced hydrogen peroxide during coleorhiza-limited germination of rice seeds. Front. Plant Sci. 2016, 7, 1219. [CrossRef] [PubMed]

32. Sobieszczuk-Nowicka, E. Polyamine catabolism adds fuel to leaf senescence. Amino Acids 2017, 49, 49-56. [CrossRef] [PubMed]

33. Yu, Y.; Zhou, W.W.; Zhou, K.J.; Liu, W.J.; Liang, X.; Chen, Y.; Sun, D.; Lin, X. Polyamines modulate aluminum-induced oxidative stress differently by inducing or reducing $\mathrm{H}_{2} \mathrm{O}_{2}$ production in wheat. Chemosphere 2018, 212, 645-653. [CrossRef] [PubMed]

34. Bagni, N.; Tassoni, A. Biosynthesis, oxidation and conjugation of aliphatic polyamines in higher plants. Amino Acids 2001, 20, 301-317. [CrossRef] [PubMed]

35. Wallace, H.M.; Fraser, A.V.; Hughes, A. A perspective of polyamine metabolism. Biochem. J. 2003, 376, 1-14. [CrossRef] [PubMed]

36. Federico, R.; Cona, A.; Angelini, R.; Schininà, M.E.; Giartosio, A. Characterization of maize polyamine oxidase. Phytochemistry 1990, 29, 2411-2414. [CrossRef]

37. Federico, R.; Ercolini, L.; Laurenzi, M.; Angelini, R. Oxidation of cetylpolyamines by maize polyamine oxidase. Phytochemistry 1996, 43, 339-341. [CrossRef]

38. Tavladoraki, P.; Shinina, M.E.; Cecconi, F.; Di Agostino, S.; Manera, F.; Rea, G.; Mariottini, P.; Federico, R.; Angelini, R. Maize polyamine oxidase, primary structure from protein and cDNA sequencing. FEBS Lett. 1998, 426, 62-66. [CrossRef]

39. Tavladoraki, P.; Rossi, M.N.; Saccuti, G.; Perez-Amador, M.A.; Polticelli, F.; Angelini, R.; Federico, R. Heterologous expression and biochemical characterization of a polyamine oxidase from Arabidopsis involved in polyamine back conversion. Plant Physiol. 2006, 141, 1519-1532. [CrossRef]

40. Tavladoraki, P.; Cona, A.; Angelini, R. Copper-containing Amine oxidases and FAD-dependent polyamine oxidases are key players in plant tissue differentiation and organ development. Front. Plant Sci. 2016, 7, 824. [CrossRef]

41. Radova, A.; Sebela, M.; Galuszka, P.; Frebort, I.; Jacobsen, S.; Faulhammer, H.G.; Pec, P. Barley polyamine oxidase, characterisation and analysis of the cofactor and the N-terminal amino acid sequence. Phytochem. Anal. 2001, 12, 166-173. [CrossRef]

42. Cervelli, M.; Cona, A.; Angelini, R.; Polticelli, F.; Federico, R.; Mariottini, P. A barley polyamine oxidase isoform with distinct structural features and subcellular localization. Eur. J. Biochem. 2001, 268, 3816-3830. [CrossRef]

43. Cervelli, M.; Polticelli, F.; Federico, R.; Mariottini, P. Heterologous expression and characterization of mouse spermine oxidase. J. Biol. Chem. 2003, 278, 5271-5276. [CrossRef] [PubMed]

44. Cervelli, M.; Di Caro, O.; Di Penta, A.; Angelini, R.; Federico, R.; Vitale, A.; Mariottini, P. A novel C-terminal sequence from barley polyamine oxidase is a vacuolar sorting signal. Plant J. 2004, 40, 410-418. [CrossRef] [PubMed]

45. Cervelli, M.; Bianchi, M.; Cona, A.; Crosatti, C.; Stanca, M.; Angelini, R.; Federico, R.; Mariottini, P. Barley polyamine oxidase isoforms 1 and 2, a peculiar case of gene duplication. FEBS J. 2006, 273, 3990-4002. [CrossRef] [PubMed]

46. Kusano, T.; Kim, D.; Liu, T.; Berberich, T. Polyamine Catabolism in Plants; Springer: Tokyo, Japan, 2015.

47. Ono, Y.; Kim, D.W.; Watanabe, K.; Sasaki, A.; Niitsu, M.; Berberich, T.; Kusano, T.; Takahashi, Y. Constitutively and highly expressed Oryza sativa polyamine oxidases localize in peroxisomes and catalyze polyamine back conversion. Amino Acids 2012, 42, 867-876. [CrossRef] [PubMed]

48. Liu, T.; Kim, D.W.; Niitsu, M.; Berberich, T.; Kusano, T. Oryza sativa polyamine oxidase 1 back-converts tetraamines, spermine and thermospermine, to spermidine. Plant Cell Rep. 2014, 33, 143-151. [CrossRef] 
49. Liu, T.B.; Kim, D.W.; Niitsu, M.; Maeda, S.; Watanabe, M.; Kamio, Y.; Berberich, T.; Kusano, T. Polyamine oxidase 7 is a terminal catabolism-type enzyme in Oryza sativa and is specifically expressed in anthers. Plant Cell Physiol. 2014, 55, 1110-1122. [CrossRef]

50. Liu, T.B.; Dobashi, H.; Kim, D.W.; Sagor, G.H.M.; Niitsu, M.; Berberich, T.; Kusano, T. Differential sensitivity to exogenous cadaverine of Arabidopsis mutants with defect in polyamine metabolic genes may be explained by spermine content in their plants. Physiol. Mol. Biol. Plants 2014, 20, 151-159. [CrossRef]

51. Kim, D.W.; Watanabe, K.; Murayama, C.; Izawa, S.; Niitsu, M.; Michael, A.J.; Berberich, T.; Kusano, T. Polyamine oxidase 5 regulates Arabidopsis growth through thermospermine oxidase activity. Plant Physiol. 2014, 165, 1575-1590. [CrossRef]

52. Mo, H.J.; Wang, X.F.; Zhang, Y.; Zhang, G.Y.; Zhang, J.F.; Ma, Z.Y. Cotton polyamine oxidase is required for spermine and camalexin signalling in the defence response to Verticillium dahlia. Plant J. 2015, 83, 962-975. [CrossRef]

53. Sagor, G.H.M.; Inoue, M.; Kim, D.W.; Kojima, S.; Niitsu, M.; Berberich, T.; Kusano, T. The polyamine oxidase from lycophyte Selaginella lepidophylla (SelPAO5), unlike that of angiosperms, back-converts thermospermine to norspermidine. FEBS Lett. 2015, 589, 3071-3078. [CrossRef]

54. Sagor, G.H.M.; Berberich, T.; Kojima, S.; Niitsu, M.; Kusano, T. Spermine modulates the expression of two probable polyamine transporter genes and determines growth responses to cadaverine in Arabidopsis. Plant Cell Rep. 2016, 35, 1247-1257. [CrossRef] [PubMed]

55. Wang, W.; Liu, J.-H. CsPAO4 of Citrus sinensis functions in polyamine terminal catabolism and inhibits plant growth under salt stress. Sci. Rep. 2016, 6, 31384. [CrossRef] [PubMed]

56. Bordenave, C.D.; Mendoza, C.G.; Bremont, J.F.J.; Garriz, A.; Rodriguez, A.A. Defining novel plant polyamine oxidase subfamilies through molecular modeling and sequence analysis. BMC Evol. Biol. 2019, 19, 28. [CrossRef] [PubMed]

57. Michael, A.J.; Furze, J.M.; Rhodes, M.J.; Burtin, D. Molecular cloning and functional identification of a plant ornithine decarboxylase cDNA. Biochem. J. 1996, 314, 241-248. [CrossRef] [PubMed]

58. Hanzawa, Y.; Imai, A.; Michael, A.J.; Komeda, Y.; Takahashi, T. Characterization of the spermidine synthase-related gene family in Arabidopsis thaliana. FEBS Lett. 2002, 527, 176-180. [CrossRef]

59. Sagor, G.H.M.; Liu, T.B.; Takahashi, H.; Niitsu, M.; Berberich, T.; Kusano, T. Longer uncommon polyamines have a stronger defense gene-induction activity and a higher suppressing activity of Cucumber mosaic virus multiplication compared to that of spermine in Arabidopsis thaliana. Plant Cell Rep. 2013, 32, 1477-1488. [CrossRef] [PubMed]

60. Sagor, G.H.M.; Kusano, T.; Berberich, T. Identification of the actual coding region for polyamine oxidase 6 from rice (OsPAO6) and its partial characterization. Plant Signal. Behav. 2017, 12, e1359456. [CrossRef] [PubMed]

61. Fincato, P.; Moschou, P.N.; Spedaletti, V.; Tavazza, R.; Angelini, R.; Federico, R.; Roubelakis-Angelakis, K.A.; Tavladoraki, P. Functional diversity inside the Arabidopsis polyamine oxidase gene family. J. Exp. Bot. 2011, 62, 1155-1168. [CrossRef] [PubMed]

62. Takahashi, T.; Kakehi, J.I. Polyamines, ubiquitous polycations with unique roles in growth and stress responses. Ann. Bot Lond. 2010, 105, 1-6. [CrossRef]

63. Hao, Y.; Huang, B.; Jia, D.; Mann, T.; Jiang, X.; Qiu, Y.; Niitsu, M.; Berberich, T.; Kusano, T.; Liu, T. Identification of seven polyamine oxidase genes in tomato (Solanum lycopersicum L.) and their expression profiles under physiological and various stress conditions. J. Plant Physiol. 2018, 228, 1-11. [CrossRef]

64. Kamada-Nobusada, T.; Hayashi, M.; Fukazawa, M.; Sakakibara, H.; Nishimura, M. A putative peroxisomal polyamine oxidase, AtPAO4, is involved in polyamine catabolism in Arabidopsis thatiana. Plant Cell Physiol. 2008, 49, 1272-1282. [CrossRef] [PubMed]

65. Fincato, P.; Moschou, P.N.; Ahou, A.; Angelini, R.; Roubelakis-Angelakis, K.A.; Federico, R.; Tavladoraki, P. The members of Arabidopsis thaliana PAO gene family exhibit distinct tissue and organ-specific expression pattern during seedling growth and flower development. Amino Acids 2012, 42, 831-841. [CrossRef] [PubMed]

66. Sequera-Mutiozabal, M.I.; Erban, A.; Kopka, J.; Atanasov, K.E.; Bastida, J.; Fotopoulos, V.; Alcázar, R.; Tiburcio, A.F. Global metabolic profiling of Arabidopsis polyamine oxidase 4 (AtPAO4) loss-of-function mutants exhibiting delayed dark-induced senescence. Front. Plant Sci. 2016, 7, 173. [CrossRef] [PubMed] 
67. Zarza, X.; Atanasov, K.E.; Marco, F.; Arbona, V.; Carrasco, P.; Kopka, J.; Fotopoulos, V.; Munnik, T.; Gómez-Cadenas, A.; Tiburcio, A.F.; et al. Polyamine oxidase 5 loss-of-function mutations in Arabidopsis thaliana trigger metabolic and transcriptional reprogramming and promote salt stress tolerance. Plant Cell Environ. 2017, 40, 527-542. [CrossRef] [PubMed]

68. Alabdallah, O.; Ahou, A.; Mancuso, N.; Pompili, V.; Macone, A.; Pashkoulov, D.; Stano, P.; Cona, A.; Angelini, R.; Tavladoraki, P. The Arabidopsis polyamine oxidase/dehydrogenase 5 interferes with cytokinin and auxin signaling pathways to control xylem differentiation. J. Exp. Bot. 2017, 68, 997-1012. [CrossRef] [PubMed]

69. Ahou, A.; Martignago, D.; Alabdallah, O.; Tavazza, R.; Stano, P.; Macone, A.; Rambla, J.L.; Vera-Sirera, F.; Angelini, R.; Federico, R.; et al. A plant spermine oxidase/dehydrogenase regulated by the proteasome and polyamines. J. Exp. Bot. 2014, 65, 1585-1603. [CrossRef] [PubMed]

70. Takahashi, Y.; Ono, K.; Akamine, Y.; Asano, T.; Ezaki, M.; Mouri, I. Highly-expressed polyamine oxidases catalyze polyamine back conversion in Brachypodium distachyon. J. Plant Res. 2018, 131, 341-348. [CrossRef] [PubMed]

71. Wang, W.; Liu, J.H. Genome-wide identification and expression analysis of the polyamine oxidase gene family in sweet orange (Citrus sinensis). Gene 2015, 555, 421-429. [CrossRef]

72. Clay, N.K.; Nelson, T. Arabidopsis thickvein mutation affects vein thickness and organ vascularization, and resides in a provascular cell-specific spermine synthase involved in vein definition and in polar auxin transport. Plant Physiol. 2005, 138, 767-777. [CrossRef]

73. Kakehi, J.; Kuwashiro, Y.; Motose, H.; Igarashi, K.; Takahashi, T. Norspermine substitutes for thermospermine in the control of stem elongation in Arabidopsis thaliana. FEBS Lett. 2010, 584, 3042-3046. [CrossRef]

74. Tsaniklidis, G.; Kotsiras, A.; Tsafouros, A.; Roussos, P.A.; Aivalakis, G.; Katinakis, P.; Delis, C. Spatial and temporal distribution of genes involved in polyamine metabolism during tomato fruit development. Plant Physiol. Biochem. 2016, 100, 27-36. [CrossRef] [PubMed]

75. Guo, Z.; Tan, J.; Zhuo, C.; Wang, C.; Xiang, B.; Wang, Z. Abscisic acid, $\mathrm{H}_{2} \mathrm{O}_{2}$ and nitric oxide interactions mediated cold-induced $S$-adenosylmethionine synthetase in Medicgo sativa subsp. falcata that confers cold tolerance through up-regulating polyamine oxidation. Plant Biotechnol. J. 2014, 12, 601-612. [PubMed]

76. Zhuo, C.; Liang, L.; Zhao, Y.; Guo, Z.; Lu, S. A cold responsive ethylene responsive factor from Medicago falcata confers cold tolerance by up-regulation of polyamine turnover, antioxidant protection, and proline accumulation. Plant Cell Environ. 2018, 41, 2021-2032. [CrossRef] [PubMed]

77. Diao, Q.; Song, Y.; Shi, D.; Qi, H. Interaction of polyamines, abscisic acid, nitric oxide, and hydrogen peroxide under chilling stress in tomato (Lycopersicon esculentum Mill.) seedlings. Front. Plant Sci. 2017, 8, 203. [CrossRef] [PubMed]

78. Parvin, S.; Lee, O.R.; Sathiyaraj, G.; Khorolragchaa, A.; Kim, Y.J.; Yang, D.C. Spermidine alleviates the growth of saline-stressed ginseng seedlings through antioxidative defense system. Gene 2014, 537, 70-78. [CrossRef]

79. Recalde, L.; Vázquez, A.; Groppa, M.D.; Benavides, M.P. Reactive oxygen species and nitric oxide are involved in polyamine-induced growth inhibition in wheat plants. Protoplasma 2018, 255, 1295-1307. [CrossRef] [PubMed]

80. Takács, Z.; Poór, P.; Tari, I. Comparison of polyamine metabolism in tomato plants exposed to different concentrations of salicylic acid under light or dark conditions. Plant Physiol. Biochem. 2016, 108, 266-278. [CrossRef] [PubMed]

81. Ozawa, R.; Bertea, C.M.; Foti, M.; Narayana, R.; Arimura, G.; Muroi, A.; Horiuchi, J.; Nishioka, T.; Maffei, M.E.; Takabayashi, J. Exogenous polyamines elicit herbivore-induced volatiles in lima bean leaves: Involvement of calcium, $\mathrm{H}_{2} \mathrm{O}_{2}$ and jasmonic acid. Plant Cell Physiol. 2009, 50, 2183-2199. [CrossRef]

82. Wang, Y.; Ye, X.; Yang, K.; Shi, Z.; Wang, N.; Yang, L.; Chen, J. Characterization, expression, and functional analysis of polyamine oxidases and their role in selenium-induced hydrogen peroxide production in Brassica rapa. J. Sci. Food Agric. 2019, 99, 4082-4093. [CrossRef]

83. Dong, Q.; Magwanga, R.O.; Cai, X.; Lu, P.; Nyangasi Kirungu, J.; Zhou, Z.; Wang, X.; Wang, X.; Xu, Y.; Hou, Y.; et al. RNA-sequencing, physiological and RNAi analyses provide insights into the response mechanism of the ABC-mediated resistance to Verticillium dahliae infection in cotton. Genes 2019, 10, 110. 
84. Jasso-Robles, F.I.; Jiménez-Bremont, J.F.; Becerra-Flora, A.; Juárez-Montiel, M.; Gonzalez, M.E.; Pieckenstain, F.L.; García de la Cruz, R.F.; Rodríguez-Kessler, M. Inhibition of polyamine oxidase activity affects tumor development during the maize-Ustilago maydis interaction. Plant Physiol. Biochem. 2016, 102, 115-124. [CrossRef] [PubMed]

85. Lulai, E.C.; Neubauer, J.D.; Olson, L.L.; Suttle, J.C. Wounding induces changes in tuber polyamine content, polyamine metabolic gene expression, and enzyme activity during closing layer formation and initiation of wound periderm formation. J. Plant Physiol. 2015, 176, 89-95. [CrossRef] [PubMed]

86. Sudhakar, C.; Veeranagamallaiah, G.; Nareshkumar, A.; Sudhakarbabu, O.; Sivakumar, M.; Pandurangaiah, M.; Kiranmai, K.; Lokesh, U. Polyamine metabolism influences antioxidant defense mechanism in foxtail millet (Setaria italica L.) cultivars with different salinity tolerance. Plant Cell Rep. 2015, 34, 141-156. [CrossRef] [PubMed]

87. Chen, T.; Xu, Y.; Wang, J.; Wang, Z.; Yang, J.; Zhang, J. Polyamines and ethylene interact in rice grains in response to soil drying during grain filling. J. Exp. Bot. 2013, 64, 2523-2538. [CrossRef] [PubMed]

88. Polticelli, F.; Salvi, D.; Mariottini, P.; Amendola, R.; Cervelli, M. Molecular evolution of the polyamine oxidase gene family in Metazoa. BMC Evol. Biol. 2012, 12, 90. [CrossRef] [PubMed]

89. Fu, X.Z.; Chen, C.W.; Wang, Y.; Liu, J.H.; Moriguchi, T. Ectopic expression of MdSPDS1 in sweet orange (Citrus sinensis Osbeck) reduces canker susceptibility: Involvement of $\mathrm{H}_{2} \mathrm{O}_{2}$ production and transcriptional alteration. BMC Plant Biol. 2011, 11, 55. [CrossRef] [PubMed]

90. Angelini, R.; Cona, A.; Federico, R.; Fincato, P.; Tavladoraki, P.; Tisi, A. Plant amine oxidases "on the move": An update. Plant Physiol. Biochem. 2010, 48, 560-564. [CrossRef]

91. Xue, B.; Zhang, A.; Jiang, M. Involvement of polyamine oxidase in abscisic acid-induced cytosolic antioxidant defense in leaves of maize. J. Integr. Plant Biol. 2009, 51, 225-234. [CrossRef]

92. Moschou, P.N.; Sarris, P.F.; Skandalis, N.; Andriopoulou, A.H.; Paschalidis, K.A.; Panopoulos, N.J.; Roubelakis-Angelakis, K.A. Engineered polyamine catabolism preinduces tolerance of tobacco to bacteria and oomycetes. Plant Physiol. 2009, 149, 1970-1981. [CrossRef]

93. Moschou, P.N.; Delis, I.D.; Paschalidis, K.A.; Roubelakis-Angelakis, K.A. Transgenic tobacco plants overexpressing polyamine oxidase are not able to cope with oxidative burst generated by abiotic factors. Physiol. Plant 2008, 133, 140-156. [CrossRef]

94. Yoda, H.; Hiroi, Y.; Sano, H. Polyamine oxidase is one of the key elements for oxidative burst to induce programmed cell death in tobacco cultured cells. Plant Physiol. 2006, 142, 193-206. [CrossRef] [PubMed]

95. Yoda, H.; Yamaguchi, Y.; Sano, H. Induction of hypersensitive cell death by hydrogen peroxide produced through polyamine degradation in tobacco plants. Plant Physiol. 2003, 132, 1973-1981. [CrossRef] [PubMed]

96. Cona, A.; Cenci, F.; Cervelli, M.; Federico, R.; Mariottini, P.; Moreno, S.; Angelini, R. Polyamine oxidase, a hydrogen peroxide-producing enzyme, is up-regulated by light and down-regulated by auxin in the outer tissues of the maize mesocotyl. Plant Physiol. 2003, 131, 803-813. [CrossRef] [PubMed]

97. Hatmi, S.; Trotel-Aziz, P.; Villaume, S.; Couderchet, M.; Clément, C.; Aziz, A. Osmotic stress-induced polyamine oxidation mediates defence responses and reduces stress-enhanced grapevine susceptibility to Botrytis cinerea. J. Exp. Bot. 2014, 65, 75-88. [CrossRef] [PubMed]

98. Aloisi, I.; Cai, G.; Serafini-Fracassini, D.; Del Duca, S. Polyamines in pollen: From microsporogenesis to fertilization. Front. Plant Sci. 2016, 7, 155. [CrossRef] [PubMed]

99. Cvikrová, M.; Gemperlová, L.; Martincová, O.; Vanková, R. Effect of drought and combined drought and heat stress on polyamine metabolism in proline-over-producing tobacco plants. Plant Physiol. Biochem. 2013, 73, 7-15. [CrossRef] [PubMed]

100. Cvikrová, M.; Gemperlová, L.; Dobrá, J.; Martincová, O.; Prásil, I.T.; Gubis, J.; Vanková, R. Effect of heat stress on polyamine metabolism in proline-over-producing tobacco plants. Plant Sci. 2012, 182, 49-58. [CrossRef]

101. Filippou, P.; Antoniou, C.; Fotopoulos, V. The nitric oxide donor sodium nitroprusside regulates polyamine and proline metabolism in leaves of Medicago truncatula plants. Free Radic. Biol. Med. 2013, 56, 172-183. [CrossRef]

102. Xiong, H.; Guo, H.; Xie, Y.; Zhao, L.; Gu, J.; Zhao, S.; Li, J.; Liu, L. RNAseq analysis reveals pathways and candidate genes associated with salinity tolerance in a spaceflight-induced wheat mutant. Sci. Rep. 2017, 7, 2731. [CrossRef] 
103. Sagor, G.H.M.; Kusano, T.; Berberich, T. Polyamine oxidase from Selaginella lepidophylla (SelPAO5) can replace AtPAO5 in Arabidopsis through converting thermospermine to norspermidine instead to spermidine. Plants 2019, 8, 99. [CrossRef]

104. Brikis, C.J.; Zarei, A.; Chiu, G.Z.; Deyman, K.L.; Liu, J.; Trobacher, C.P.; Hoover, G.J.; Subedi, S.; DeEll, J.R.; Bozzo, G.G.; et al. Targeted quantitative profiling of metabolites and gene transcripts associated with 4-aminobutyrate (GABA) in apple fruit stored under multiple abiotic stresses. Hortic. Res. 2018, 5, 61. [CrossRef] [PubMed]

105. Xu, X.; Shi, G.; Jia, R. Changes of polyamine levels in roots of Sagittaria sagittifolia L. under copper stress. Environ. Sci. Pollut. Res. Int. 2012, 19, 2973-2982. [CrossRef] [PubMed]

106. Yang, H.; Shi, G.; Wang, H.; Xu, Q. Involvement of polyamines in adaptation of Potamogeton crispus L. to cadmium stress. Aquat. Toxicol. 2010, 100, 282-288. [CrossRef] [PubMed]

107. Cona, A.; Moreno, S.; Cenci, F.; Federico, R.; Angelini, R. Cellular re-distribution of flavin-containing polyamine oxidase in differentiating root and mesocotyl of Zea mays L. seedlings. Planta 2005, 221, 265-276. [CrossRef] [PubMed]

108. Rea, G.; de Pinto, M.C.; Tavazza, R.; Biondi, S.; Gobbi, V.; Ferrante, P.; De Gara, L.; Federico, R.; Angelini, R.; Tavladoraki, P. Ectopic expression of maize polyamine oxidase and pea copper amine oxidase in the cell wall of tobacco plants. Plant Physiol. 2004, 134, 1414-1426. [CrossRef] [PubMed]

109. Gomez-Jimenez, M.C.; Paredes, M.A.; Gallardo, M.; Sanchez-Calle, I.M. Mature fruit abscission is associated with up-regulation of polyamine metabolism in the olive abscission zone. J. Plant Physiol. 2010, 167, 1432-1441. [CrossRef]

110. Paschalidis, K.A.; Roubelakis-Angelakis, K.A. Sites and regulation of polyamine catabolism in the tobacco plant. Correlations with cell division/expansion, cell cycle progression, and vascular development. Plant Physiol. 2005, 138, 2174-2184. [CrossRef] [PubMed]

111. Wu, J.; Shang, Z.; Wu, J.; Jiang, X.; Moschou, P.N.; Sun, W.; Roubelakis-Angelakis, K.A.; Zhang, S. Spermidine oxidase-derived $\mathrm{H}_{2} \mathrm{O}_{2}$ regulates pollen plasma membrane hyperpolarization-activated $\mathrm{Ca}^{2+}$-permeable channels and pollen tube growth. Plant J. 2010, 63, 1042-1053. [CrossRef]

112. Agudelo-Romero, P.; Bortolloti, C.; Pais, M.S.; Tiburcio, A.F.; Fortes, A.M. Study of polyamines during grape ripening indicate an important role of polyamine catabolism. Plant Physiol. Biochem. 2013, 67, 105-119. [CrossRef]

113. Planas-Portell, J.; Gallart, M.; Tiburcio, A.F.; Altabella, T. Copper-containing amine oxidases contribute to terminal polyamine oxidation in peroxisomes and apoplast of Arabidopsis thaliana. BMC Plant Biol. 2013, 13, 109. [CrossRef]

(C) 2019 by the authors. Licensee MDPI, Basel, Switzerland. This article is an open access article distributed under the terms and conditions of the Creative Commons Attribution (CC BY) license (http://creativecommons.org/licenses/by/4.0/). 